Научная статья

Удк 502.5(203) - 027.231

DOI https://doi.org/10.24866/VVSU/2073-3984/2021-4/199-213

И.Ю. Гриванов ${ }^{1}$

Е.В. Тарасова ${ }^{2}$

И.В. Кучма ${ }^{3}$

Владивостокский государственный университет экономики и сервиса

Владивосток. Россия

\title{
Прогнозирование состояния атмосферного воздуха в результате деятельности Новоспасского цементного завода АО «Спасскцемент»
}

\begin{abstract}
Аннотация. Атмосфера является средой, в которую выбрасываются отходы жизнедеятельности человека, животных и растений. Промышленные предприятия и транспорт - основные источники этих выбросов. Охрана атмосферного воздуха начинается с предприятий: с экологического мониторинга на предприятии и с определения предельно допустимых норм воздействия на окружающую природную среду, гарантирующих экологическую безопасность населения. Целью данной научной работы является определение уровня загрязнения атмосферы вредными веществами, содержащимися в выбросах Новоспасского цементного завода АО «Спасскцемент». Методическую основу работы составляет авторская оценка воздействия выбросов загрязняющих веществ на атмосферный воздух с использованием методов измерения и сравнительного анализа. Основное внимание в работе уделяется количественной оценке воздействия выбросов загрязняющих веществ на атмосферный воздух от 112 источников, расположенных на территории Новоспасского цементного завода АО «Спасскцемент». Проведена оценка выбросов по классам опасности. Выполнен расчет рассеивания загрязняющих веществ в атмосферном воздухе в районе расположения предприятия с учетом фона по 34 загрязняющим веществам и 5 группам суммации для зимнего и летнего периодов. Проведен сравнительный анализ расчетного загрязнения атмосферы с оценкой загрязнения ФГБУ «Приморское УГМС». Результаты исследования свидетельствуют о том, что прогнозируемый уровень загрязнения атмосферы, полученный расчетным путем, оценивается
\end{abstract}

1 Гриванов Игорь Юрьевич - доцент кафедры туризма и экологии. ORCID: https://orcid.org/0000-0002-7171-601X; e-mail: Igor.Grivanov @ vvsu.ru

2 Тарасова Елена Валерьевна - доцент кафедры туризма и экологии. ORCID: https://orcid.org/0000-0002-2254-6042; e-mail: Elena.Tarasova@ vvsu.ru

3 Кучма Ирина Викторовна - магистрант; e-mail: Irina.Kuchma19@vvsu.ru 
как «низкий», что совпадает с оценкой ФГБУ «Приморское УГМС». Научная новизна исследования заключается в применении расчетного метода для подтверждения инструментальных измерений.

Ключевые слова: загрязняющее (вредное) вещество, источник загрязнения атмосферы, предельно допустимая концентрация, предельно допустимый выброс, санитарно-защитная зона.

\title{
I.Yu. Grivanov
}

\section{E.V. Tarasova}

\section{I.V. Kuchma}

Vladivostok State University of Economics and Service Vladivostok. Russia

\section{Forecasting the state of atmospheric air as a result of the activities of the Novospassky cement plant JSC "Spasskcement"}

\begin{abstract}
The atmosphere is the environment into which human, animal and plant waste is discharged. Industry and transport are the main sources of these emissions. The protection of atmospheric air begins with enterprises: with environmental monitoring at the enterprise and with the determination of the maximum permissible norms for the impact on the natural environment, which guarantee the ecological safety of the population. The purpose of this scientific work is to determine the level of atmospheric pollution by harmful substances contained in the emissions of the Novospassky cement plant JSC "Spasskcement". The methodological basis of the work is the author's assess-ment of the impact of pollutant emissions on the air using measurement methods and comparative analysis. The main attention in the work is paid to the quantitative assessment of the impact of emissions of pollutants on the at-mospheric air from 112 sources located on the territory of the Novospassky cement plant JSC "Spasskcement". Emissions were assessed by hazard classes. The calculation of the dispersion of pollutants in the atmospheric air of the area where the enterprise is located was carried out, taking into account the background for 34 pollutants and 5 groups of summation for the winter and summer periods. A comparative analysis of the calculated air pollution with the assessment of pollution by the FGBU "Primorskoe UGMS" has been carried out. The results of the study indi-cate that the predicted level of atmospheric pollution, obtained by calculation, is assessed as "low", which coincides with the assessment of the FSBI "Primorskoe UGMS". The scientific novelty of the research lies in the application of the calculation method to confirm instrumental measurements.
\end{abstract}

Keywords: polluting (harmful) substance; source of pollution of the atmosphere; maximum permissible concentration; maximum permissible emission; sanitary protection zone.

\section{Введение}

Атмосферный воздух - один из жизненно важных компонентов окружающей среды. Без воздуха не было бы жизни на нашей планете: он является источ- 
ником дыхания всего живого, служит сырьем для процессов горения и химического синтеза различных веществ. В то же время воздух - это среда, в которую поступают как отходы жизнедеятельности всего живого, так и отходы природной деятельности.

Основными загрязнителями воздуха являются предприятия и автотранспорт. Каждая страна по-своему решает эту проблему. Базовым законом в российском природоохранном законодательстве является Федеральный закон от 10 января 2002 года № 7 «Об охране окружающей среды». Периодически происходит редактирование этого закона. На сегодняшний день действует редакция от 02.07.2021. Допустимость воздействия того или иного объекта устанавливается многочисленными природоохранными документами.

Актуальность данной работы - расчет нормативов выбросов в атмосферный воздух для определения допустимого негативного воздействия на окружающую среду конкретного предприятия.

Рассматриваемая проблема и ее практическая значимость послужили основой для формулирования цели исследовательской работы и ее задач.

Целью работы является определение уровня загрязнения атмосферы вредными веществами, содержащимися в выбросах, осуществляемых с территории Новоспасского цементного завода АО «Спасскцемент».

Для осуществления цели был поставлен ряд задач:

1) провести инвентаризацию источников загрязнения атмосферы на промплощадке исследуемого предприятия;

2) рассчитать максимально-разовый и валовый выброс от всех источников на промплощадке;

3) распределить выбрасываемые вещества по классам опасности;

4) рассчитать загрязнение атмосферы, создаваемое источниками исследуемого предприятия;

5) сравнить расчетное загрязнение атмосферы с оценкой Приморского УГМС.

Воздействие загрязняющих веществ на атмосферный воздух на примере Акционерного общества «Спасскцемент» (АО «Спасскцемент») является предметом исследования данной работы.

Работы многих авторов посвящены проблеме охраны окружающей среды на действующих предприятиях $[10,11]$, воздействию вредных веществ на человека и окружающую среду [1-4].

Однако что касается конкретных предприятий, то для решения вышеназванных проблем специалистами-экологами используются методы расчетов рассеивания выбросов вредных (загрязняющих) веществ (3В) в атмосферном воздухе (MPP-2017) [6].

В нашем случае согласно ст. 32 Федерального закона «Об охране окружающей среды» для хозяйственной деятельности, которая оказывает воздействие на атмосферный воздух, проводится оценка воздействия на этот компонент [12]. Оценка негативного воздействия на окружающую среду (НВОС) зависит от катего- 
рии объектов. Согласно ст. 4.2 Федерального закона [12] все хозяйствующие объекты в зависимости от уровня воздействия подразделяются на четыре категории.

К первой категории относятся объекты, оказывающие значительное негативное воздействие на окружающую среду; ко второй категории - объекты, оказывающие умеренное негативное воздействие; к третьей категории - объекты, оказывающие незначительное негативное воздействие; к четвертой категории объекты, оказывающие минимальное воздействие.

АО «Спасскцемент» занимается выпуском цементной продукции. Категория объекта НВОС - первая. К этой категории относятся предприятия, которые без специальных защитных мероприятий создают высокие и очень высокие уровни загрязнения атмосферы, во много раз превышающие нормативные значения.

Для снижения воздействия на атмосферу выбросов таких предприятий необходимо проведение целого комплекса природоохранных мероприятий по снижению выбросов загрязняющих веществ. Кроме того, необходим постоянный контроль за их выбросами.

Деятельность учреждения в рамках настоящей работы рассматривается на одной производственной площадке - на Новоспасском цементном заводе (НСЦЗ).

В состав площадки входят три подразделения:

- Новоспасский цементный завод;

- Длинногорский карьер известняка;

- Кулешовский карьер глин.

Режим работы - 365 дней в году, 24 часа в сутки.

В табл. 1 показаны все источники загрязнения атмосферы для исследуемой производственной площадки.

На площадке имеется 112 источников выбросов загрязняющих веществ в атмосферный воздух.

Таблиия 1

Распределение источников выбросов загрязняющих веществ по подразделениям

\begin{tabular}{|l|c|c|c|}
\hline \multirow{2}{*}{$\begin{array}{l}\text { Подразделения АО «Спасскце- } \\
\text { мент» }\end{array}$} & \multicolumn{3}{|c|}{ Количество, шт. } \\
\cline { 2 - 4 } & \multicolumn{2}{|c|}{ Источники загрязнения атмосферы } \\
\cline { 2 - 4 } & Организованные & Неорганизованные & Всего \\
\hline НСЦЗ & 74 & 15 & 89 \\
\hline $\begin{array}{l}\text { Длинногорский карьер извест- } \\
\text { няка }\end{array}$ & 10 & 12 & 22 \\
\hline Кулешовский карьер глин & & 1 & 112 \\
\hline Всего: & 84 & 28 & 1 \\
\hline
\end{tabular}


И.Ю. Гриванов и др. Прогнозирование состояния атмосферного воздуха...

От этих источников в атмосферу поступает 34 загрязняющих вещества (17 твердых и 17 жидких и газообразных), выбросы которых показаны в табл. 2.

Таблииа 2

\section{Распределение выбросов загрязняющих веществ по подразделениям}

\begin{tabular}{|l|c|c|c|}
\hline \multirow{2}{*}{$\begin{array}{c}\text { Подразделения АО } \\
\text { «Спасскцемент» }\end{array}$} & \multicolumn{3}{|c|}{ Количество, т/год } \\
\cline { 2 - 4 } & Организованные & Неорганизованные & Всего \\
\cline { 2 - 4 } & 1370,2128011 & 64,4414113 & 1434,6542124 \\
\hline НСЦ3 & 35,7401448 & 69,6584883 & 105,3986331 \\
\hline $\begin{array}{l}\text { Длинногорский карьер } \\
\text { известняка }\end{array}$ & 1405,9529459 & 139,8797156 & 1545,8326615 \\
\hline $\begin{array}{l}\text { Кулешовский карьер } \\
\text { глин }\end{array}$ & & & 5,7798160 \\
\hline Всего: & & & \\
\hline
\end{tabular}

Выбросы 17 твердых загрязняющих веществ составляют 1087,0184968 т/год, или $70,32 \%$ от общего количества выбросов, жидких/газообразных 458,8139040 т/год, или $29,68 \%$.

Из всего количества выбросов 99,91\% приходится на 9 веществ.

Распределение выбросов показано на рис. 1.

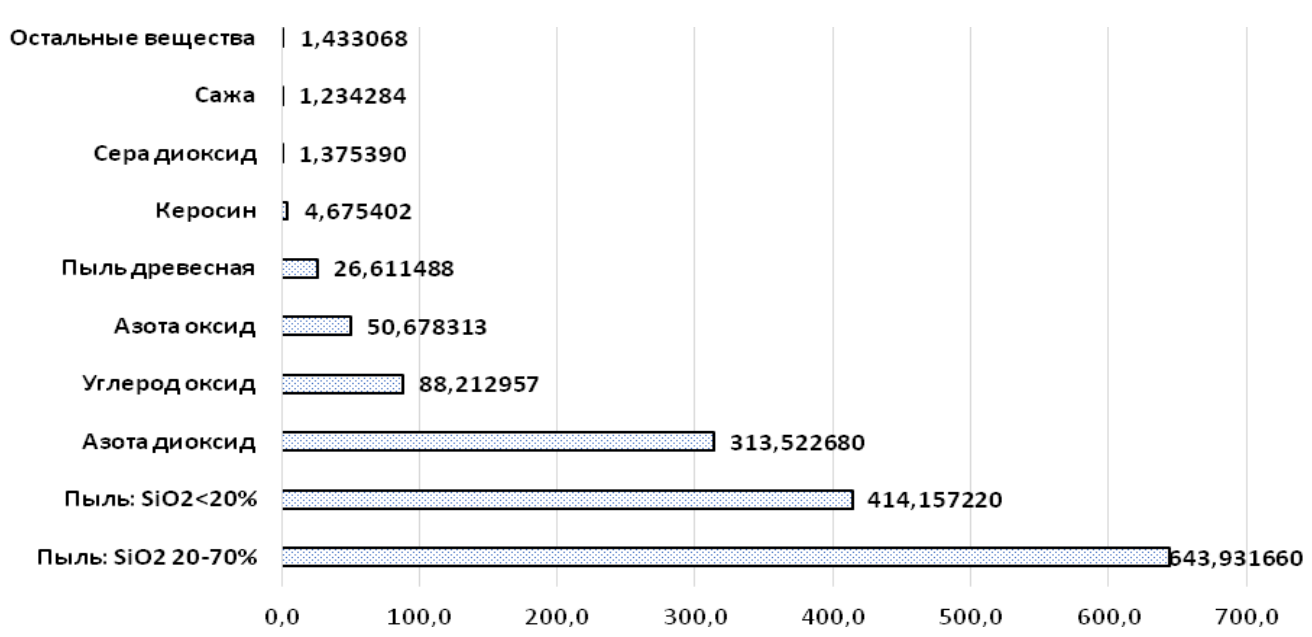

Рис. 1. Распределение выбросов ЗВ от источников АО «Спасскцемент», т/год

Как видно из рисунка, наибольшая доля выбросов приходится на вещество 2909 (пыль неорганическая: $\mathrm{SiO} 2$ 20-70 \%); составляет 41,66 \% от общего количества выбросов. Кроме того, значительную долю выбросов $(26,79 \%)$ форми- 
рует вещество 2908 (пыль неорганическая: $\mathrm{SiO} 2<20 \%$ ). В совокупности доля этих двух твердых веществ составляет $68,45 \%$ от общего количества выбросов. Выбросы оставшихся 15 твердых веществ незначительны: 28,9296168 т/год, или $1,87 \%$ от общего количества выбросов.

Из жидких/газообразных веществ наибольшая доля приходится на вещества: 0301 (азота диоксид) - 20,28 \%, 0337 (углерод оксид) - 5,71\% и 0304 (азота оксид) $-3,28 \%$. Доля этих трех веществ $-29,27 \%$ от общих выбросов, т.е. на долю оставшихся 14 жидких/газообразных веществ приходится $0,41 \%$.

В выбросах рассматриваемого предприятия содержатся вещества всех классов опасности, включая вещества без класса опасности с установленным ориентировочно безопасным уровнем воздействия (ОБУВ) (рис. 2).

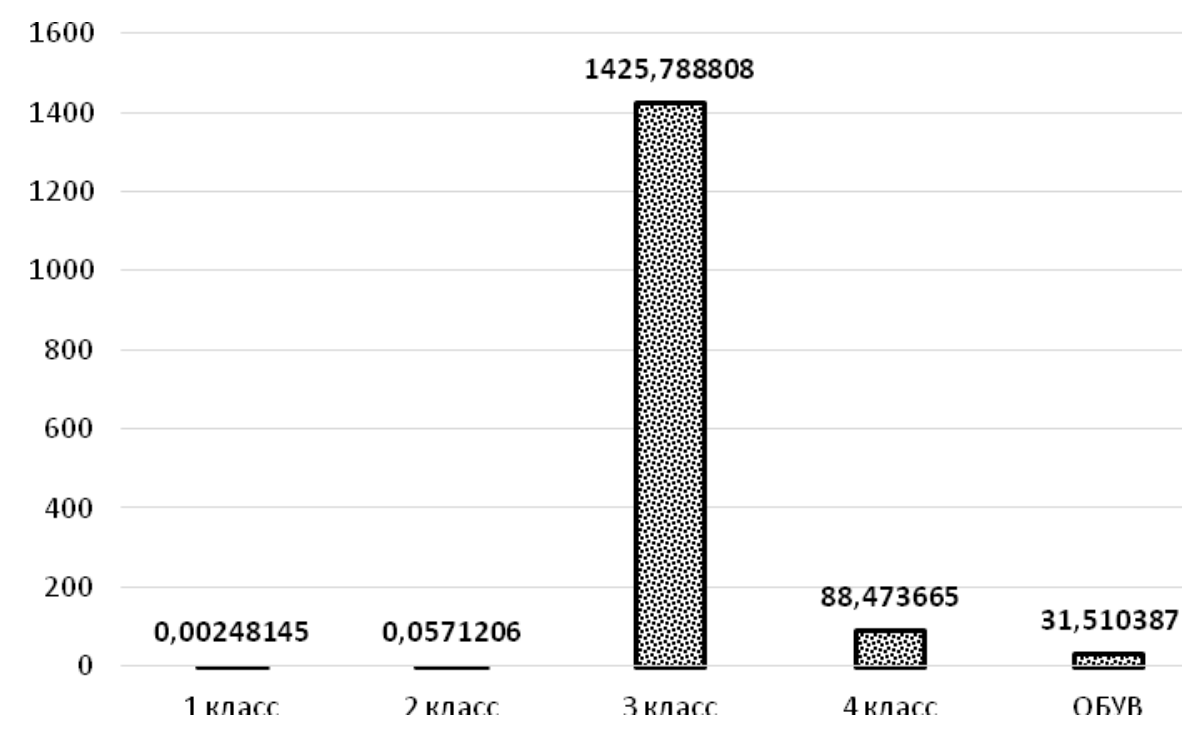

Рис. 2. Классы опасности выбрасываемых 3В, т/год

Из четырех загрязняющих веществ 1-го класса 99,46\% от выбросов приходится на одно вещество 0203 (хром) и составляет 0,002468 т/год. Доля выбросов веществ 1-го класса в общем количестве - менее $0,001 \%$.

Выбросы восьми веществ 2-го класса составляют 0,0571206 т/год, или $0,004 \%$ от общего количества выбросов.

Вещества 3-го класса опасности вносят максимальное количество выбросов - 1425,788808 т/год, или $92,23 \%$ от общего количества. К этому классу относятся 13 загрязняющих веществ. Причем доля четырех веществ (два твердых пыли неорганические и два жидких/газообразных - оксиды азота) составляет 99,75 \% от выбросов этого класса - 1422,289873 т/год. Вклад остальных незначителен.

Доля выбросов веществ 4-го класса - 5,72 \% от общего количества, или 88,473665 т/год. Но из пяти веществ этого класса 99,97 \% приходится на одно 
вещество 0337 (углерод оксид), выбросы которого составляют 88,212957 т/год. Вклад остальных веществ незначителен.

Выбросы четырех веществ с установленным ОБУВ - 31,510387 т/год, или $2,04 \%$. Большую часть выбросов - 26,611488 т/год вносит вещество 2936 (пыль древесная).

На 79 источников загрязнения атмосферы из 112 установлены пылегазоочистные системы, предназначенные для уменьшения выброса в атмосферный воздух загрязняющих веществ основного производства НСЦЗ. В качестве аспирационных систем очистки используют рукавные фильтры СМЦ-101 и ФРКИ-60, циклоны типа ЦН-15, унифицированные электрофильтры серии УГ. Эффективность очистки установлена по данным предприятия, на основании протоколов замеров, выполненных аттестованной санитарно-промышленной лабораторией.

Работа очистного оборудования не просто снижает количество выбросов загрязняющих веществ, а очень сильно снижает. Без существующего очистного оборудования твердых загрязняющих веществ выбрасывалось бы больше чем в 200 раз, жидких и газообразных - в 400 раз. Общее количество выбросов достигало бы 417 тыс. т/год, тогда как на существующий момент общее количество выбросов чуть превышает 1,5 тыс. т/год, т.е. без очистного оборудования работа Новоспасского цементного завода была бы невозможна.

ФГБУ «Приморское УГМС» не проводит мониторинг загрязнения атмосферного воздуха в г. Спасске-Дальнем, поэтому загрязнение формально считается низким [5]. Вследствие этого были проведены расчеты загрязнения атмосферы и внесены предложения по нормативам предельно допустимого выброса (ПДВ) предприятия.

Согласно п. 2.4 СанПиН 2.2.1/2.1.1.1200-03 [9] для подразделения «Новоспасский цементный завод» АО «Спасскцемент» устанавливается расчетная санитарно-защитная зона с учетом суммарных выбросов в атмосферный воздух. Размеры зоны варьируются от 100 до 500 м.

Основываясь на требованиях СанПиН 1.2.3685-21 [8], был определен общий максимально-разовый выброс от всех источников загрязнения для расчета приземной концентрации по каждому веществу. Причем расчеты проводились для самыХ неблагоприятных условий выбросов, которые могут быть на предприятии.

В жилой зоне и на других территориях проживания должны соблюдаться 1 ПДК (предельно допустимая концентрация) и 0,8 ПДК - в местах массового отдыха населения, на территориях размещения лечебно-профилактических учреждений, длительного пребывания больных и центров реабилитации, в том числе и общеобразовательных дошкольных учреждений [8].

В качестве данных для расчетов были приняты максимально-разовые выбросы веществ, параметры источников выбросов, включающие их координаты, высоту, размеры, объем и температуру выбрасываемой газовоздушной смеси, метеорологические характеристики и коэффициенты. Все это позволило рассчитать поле рассеивания вредных веществ в приземном слое атмосферы. Кроме того, для расчетов использовалась климатическая характеристика, выданная ФГБУ «Приморское УГМС». 
Детальный расчет рассеивания загрязняющих веществ в атмосферном воздухе производственной площадки предприятия с учетом фона проводился по 34 загрязняющим веществам и 5 группам суммации. Расчет проводился на зимний и летний периоды.

За расчетную площадку была принята область 4000х5000 м, в которую входила зона влияния выбросов предприятия.

Система координат площадки учреждения привязана к локальной системе координат. За ноль системы координат был принят юго-западный угол территории.

Для расчета были приняты 12 расчетных точек на границе ориентировочной санитарно-защитной зоны (С33), жилой застройки и особо охраняемой зоны. Координаты расчетных точек приведены в табл. 3.

Таблийа 3

Параметры расчетных точек

\begin{tabular}{|c|c|c|c|c|}
\hline \multirow[t]{2}{*}{ Наименование } & \multicolumn{3}{|c|}{ Координаты } & \multirow[t]{2}{*}{ Тип точки } \\
\hline & $\mathrm{X}$ & $\mathrm{Y}$ & Высота, м & \\
\hline $\begin{array}{l}\text { 1. Жилой дом по адресу: } \\
\text { ул. Сопочная, } 11\end{array}$ & 977,1 & 2971,1 & 2 & $\begin{array}{l}\text { Точка в жилой } \\
\text { зоне }\end{array}$ \\
\hline $\begin{array}{l}\text { 2. Жилой дом по адресу: } \\
\text { ул. Репина, } 1\end{array}$ & 1867,2 & 3237,8 & 2 & $\begin{array}{l}\text { Точка в жилой } \\
\text { зоне }\end{array}$ \\
\hline 3. Граница С33, север & $-1058,43$ & 3204,16 & 2 & $\begin{array}{l}\text { Точка на границе } \\
\text { С33 }\end{array}$ \\
\hline 4. Граница С33, север & 883,29 & 2740,03 & 2 & $\begin{array}{l}\text { Точка на границе } \\
\text { С33 }\end{array}$ \\
\hline $\begin{array}{l}\text { 5. Граница С33, северо- } \\
\text { восток }\end{array}$ & 1795,08 & 3056,77 & 2 & $\begin{array}{l}\text { Точка на границе } \\
\text { С33 }\end{array}$ \\
\hline 6. Граница С33, восток & 2430,37 & 2299,08 & 2 & $\begin{array}{l}\text { Точка на границе } \\
\text { С33 }\end{array}$ \\
\hline $\begin{array}{l}\text { 7. Граница С33, юго- } \\
\text { восток }\end{array}$ & 2318,77 & 1408,83 & 2 & $\begin{array}{l}\text { Точка на границе } \\
\text { С33 }\end{array}$ \\
\hline 8. Граница С33, юг & 1253,11 & 637,55 & 2 & $\begin{array}{l}\text { Точка на границе } \\
\text { С33 }\end{array}$ \\
\hline 9. Граница С33, юг & $-22,97$ & $-96,08$ & 2 & $\begin{array}{l}\text { Точка на границе } \\
\text { С33 }\end{array}$ \\
\hline $\begin{array}{l}\text { 10. Граница С33, юго- } \\
\text { запад }\end{array}$ & $-652,18$ & 499,84 & 2 & $\begin{array}{l}\text { Точка на границе } \\
\text { С33 }\end{array}$ \\
\hline 11. Граница С33, запад & $-940,87$ & 1415,27 & 2 & $\begin{array}{l}\text { Точка на границе } \\
\text { С33 }\end{array}$ \\
\hline $\begin{array}{l}\text { 12. Граница С } 33 \text {, северо- } \\
\text { запад }\end{array}$ & $-1488,08$ & 2503,13 & 2 & $\begin{array}{l}\text { Точка на границе } \\
\text { С33 }\end{array}$ \\
\hline
\end{tabular}


Наибольшие приземные концентрации приходятся на три вещества: пыль неорганическую: SiO2 20-70\%, пыль неорганическую: $\mathrm{SiO}<20 \%$ и азота диоксид, т.е. на те вещества, которые дают максимальный вклад в количество выбросов. Суммарная доля этих трех веществ составляет 1371,611560 т/год, или $88,72 \%$ от общего количества выбросов.

Наибольший вклад в выбросы этих веществ вносят три источника. Рассмотрим их подробнее.

Источник № 6208, неорганизованный, высота - 2 м. Работа в карьере.

Производство цемента начинается с добычи известняка, которая ведется открытым способом с применением буровзрывных работ в карьере. Ежегодно на карьере добывается 2833,335 тыс. т известняка.

Известняк - осадочная горная порода с содержанием $\mathrm{SiO} 2-5 \%$ и влажностью не более $1 \%$ (согласно протоколу СТП 00282754-1.01-18 от 25.01.2018).

В карьере работают буровые станки: 2 штуки - СБШ-250МН, 1 штукаDRILTECH D25KS, оборудованные системой водовоздушного подавления.

При полной производительности завода в карьере производится 52 взрыва. Величина заряда - 12,76 т, марка взрывчатых веществ - граммонит 79/21.

Отбитый известняк и образующиеся при его добыче вскрышные породы грузятся экскаваторами HITACHI ZX-850, -450 в автосамосвалы VOLVO FM $6 \times 4$ грузоподъёмностью 205 т (ежесменно в карьере работают в среднем 7 автосамосвалов; в смену осуществляется до 37 рейсов каждым автосамосвалом; итого 259 рейсов $\times 25$ т = 6475 т). Зачистка подошвы под экскаватором, зачистка автодорог выполняются бульдозерами KOMATSU.

Источники № 110 и 112, организованные, высота - 30 м, диаметр трубы 2,5 м, эффективность очистки - 99,8 и 99,7\%. Мельница «Аэрофол» и печь.

Со склада через систему транспортеров известняк и глина подаются на мельницы самоизмельчения печей № $1,2$.

Для помола сырья в крупку и сушки в сырьевом отделении установлены два комплекса оборудования, включающих в себя мельницы самоизмельчения «Аэрофол» и вращающиеся печи следующих марок: комплекс № 1 «Аэрофол» Фив Лиль Кай 8,68×2,2 м, производительность - 260 т/ч, вращающаяся печь СМЦ-44-1 7,64×95 м, производительность - 145 т/ч; комплекс № 2 «Аэрофол» СММ-46 9,7×3,32 м, производительность - 260 т/ч, вращающаяся печь СМЦ-44-1 7,64×95 м, производительность - 140 т/ч.

Каждый такой комплекс оборудован единой системой отвода и очистки отходящих газов. Постоянно в работе находится один комплекс «мельница + печь», второй остается в резерве. Одновременная работа двух комплексов не предусмотрена. В качестве сушильного агента используются отходящие газы циклонных теплообменников вращающихся печей с температурой $350{ }^{\circ} \mathrm{C}$. Очистка газов осуществляется в электрофильтрах УГ2-4-74. На каждую технологическую линию (каждый комплекс) установлено три электрофильтра.

Производительность каждого комплекса - 3480/3360 т/ч, общая производительность цеха - 1710000 т/год. 
Высота источников - 18 м, диаметр - 2,5 м. Время работы - 6000 ч/год для комплекса № 1, 6000 ч/год для комплекса № 2.

Скорость выхода газовоздушной смеси для комплекса оборудования № 1 $26,95 \mathrm{~m}^{3} / \mathrm{c}$, для комплекса оборудования № $2-28,5 \mathrm{~m}^{3} / \mathrm{c}$.

Суммарная эффективность очистки на 3 электрофильтрах для комплекса № $1-99,8 \%$; для комплекса № $2-99,7 \%$.

Вышеперечисленные источники дают максимальный вклад в приземные концентрации.

Рассмотрим максимальные приземные концентрации загрязняющих веществ.

Вещество 0301 (азота диоксид).

Класс опасности вещества - 3. Предельно допустимая концентрация в атмосферном воздухе населённых мест составляет $0,2 \mathrm{Mг} / \mathrm{M}^{3}$.

Количество источников загрязнения атмосферы - 17 , в том числе организованных - 3, неорганизованных - 14 .

Максимально-разовый выброс от всех источников - 20,175744 г/с.

Поле рассеивания вещества показано на рис. 3.

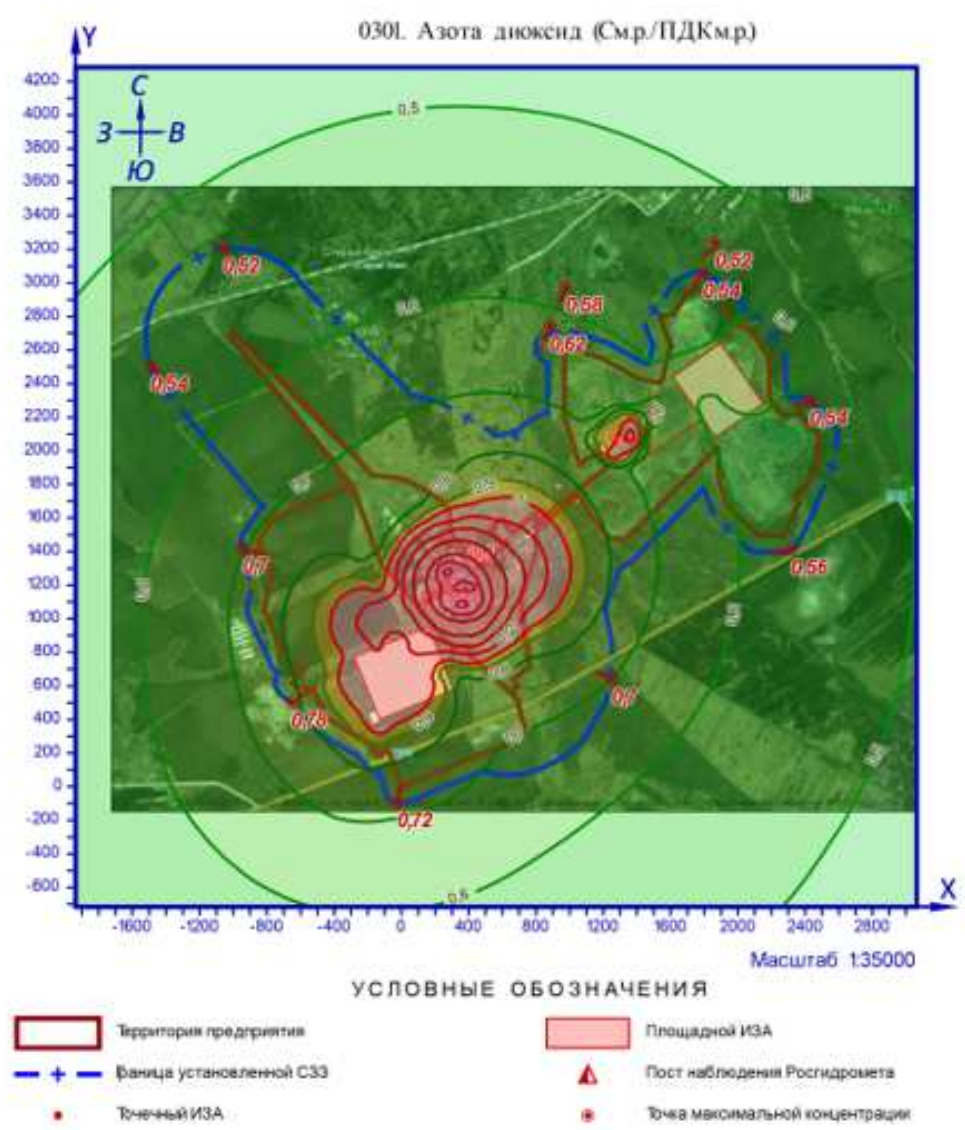

Рис. 3. Поле рассеивания вещества 0301 (азота диоксид) 
Максимальная разовая расчётная концентрация на границе С33 составляет 0,78 долей ПДК при направлении ветра $54^{\circ}$, скорости ветра 4,3 м/с; в жилой зоне $-0,58$ долей ПДК при направлении ветра $203^{\circ}$, скорости ветра 5,5 м/с.

Вещество 2908 (пыль неорганическая: $\mathrm{SiO} 2$ 20-70 \%).

Пыль неорганическая, содержащая 70-20 \% двуокиси кремния. Класс опасности - 3. ПДК в атмосферном воздухе населённых мест составляет $0,1 \mathrm{mг} / \mathrm{m}^{3}$.

Поле рассеивания вещества показано на рис. 4.

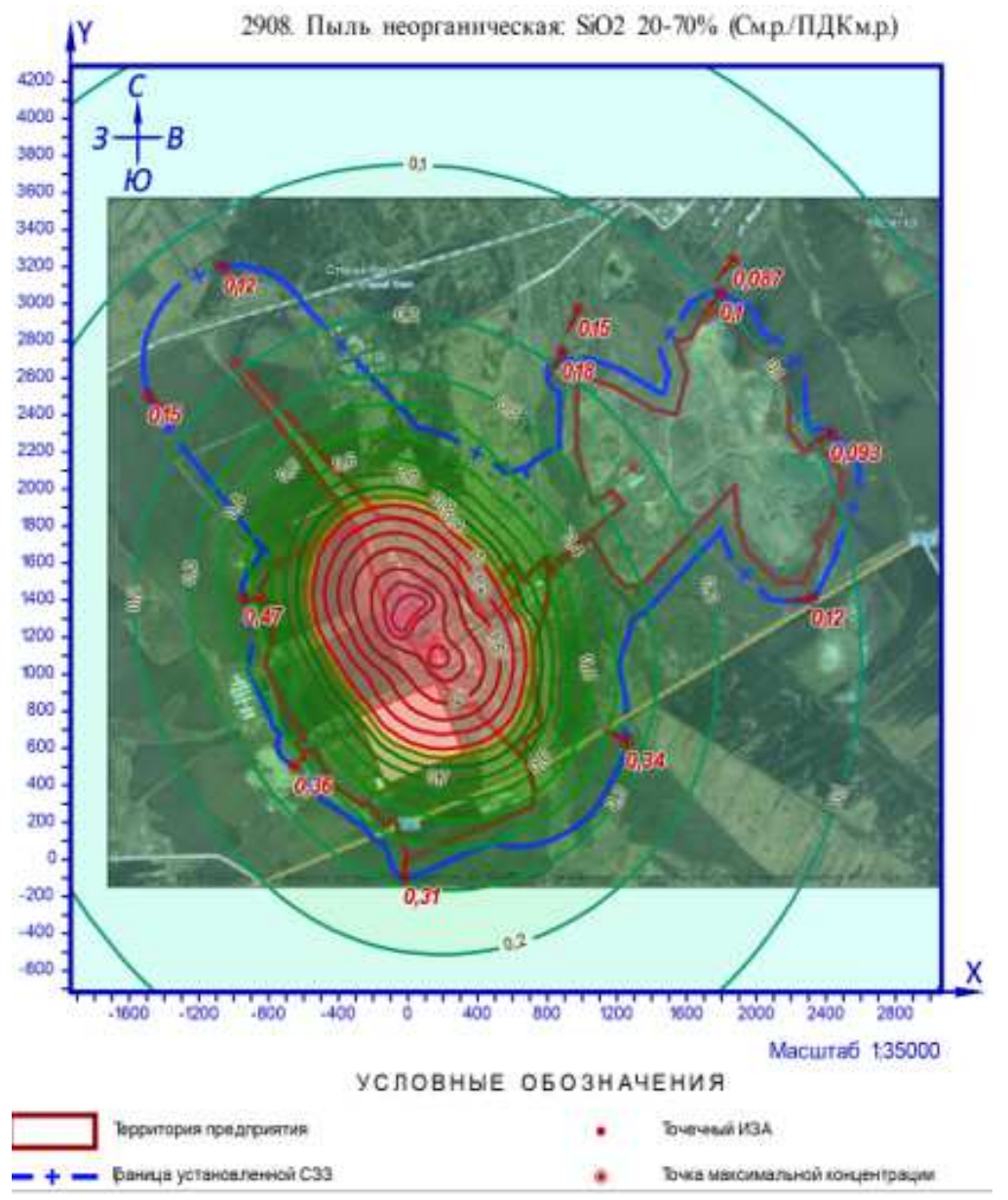

Рис. 4. Поле рассеивания вещества 2908 (пыль неорганическая: SiO2 20-70 \%)

Количество источников загрязнения атмосферы - 19, в том числе организованных -15 , неорганизованных -4 .

Максимально-разовый выброс от всех источников - 18,827812 г/с.

Максимальная разовая расчётная концентрация на границе С33 составляет 0,47 долей ПДК при направлении ветра $99^{\circ}$, скорости ветра 4,4 м/с; в жилой зоне $-0,15$ долей ПДК при направлении ветра $207^{\circ}$, скорости ветра 5,5 м/с. 
Вещество 2909 (пыль неорганическая: $\mathrm{SiO}<20 \%$ ).

Пыль неорганическая, содержащая менее $20 \%$ двуокиси кремния. Класс опасности - 3. ПДК в атмосферном воздухе населённых мест составляет $0,5 \mathrm{M \Gamma} / \mathrm{M}^{3}$.

Поле рассеивания вещества показано на рис. 5 .

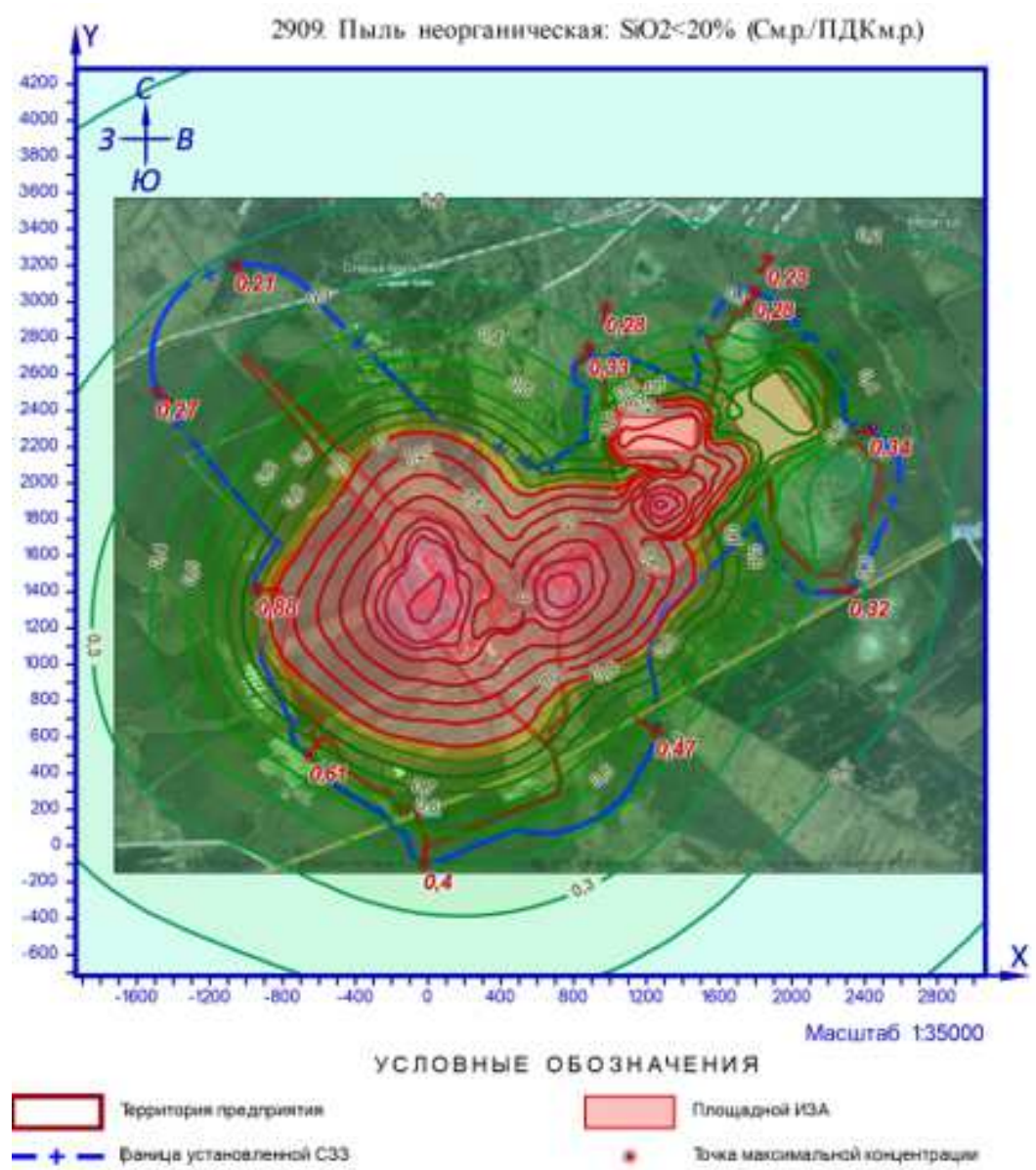

Рис. 5. Поле рассеивания вещества 2909 (пыль неорганическая: $\mathrm{SiO} 2<20 \%$ )

Количество источников загрязнения атмосферы составляет - 71 , в том числе организованных - 65, неорганизованных - 6 .

Максимально-разовый выброс от всех источников - 48,508083 г/с.

Максимальная разовая расчётная концентрация на границе С33 составляет 0,88 долей ПДК при направлении ветра $93^{\circ}$, скорости ветра 5,5 м/с; в жилой зоне - 0,28 долей ПДК при направлении ветра $187^{\circ}$, скорости ветра 0,5 м/с.

Концентрации остальных веществ значительно ниже и поэтому в данной работе рассматриваться не будут. 


\section{Выводы}

В ходе исследования поставлены и выполнены задачи, позволившие определить следующее:

- на территории производственной площадки Новоспасского цементного завода $\mathrm{AO}$ «Спасскцемент» установлено 112 источников загрязнения атмосферы, в том числе 84 организованных и 28 неорганизованных;

- валовый выброс составляет 1545,8326615 т/год, в том числе твердые вещества - 1087,0184968 т/год, жидкие/газообразные - 458,8139040 т/год;

- в выбросах предприятия присутствуют вещества всех классов опасности, включая ОБУВ;

- расчетные максимальные концентрации загрязняющих веществ с учетом фонового загрязнения в рассматриваемом районе не превысили ПДК на границе санитарно-защитной зоны и жилой застройки;

- прогнозируемый уровень загрязнения атмосферы, полученный расчетным путем, оценивается как «низкий», что совпадает с оценкой ФГБУ «Приморское УГМС».

Научная новизна исследования заключается в применении расчетного метода для подтверждения инструментальных замеров.

1. Влияние на человека отработавших газов автомобилей. - Текст: электронный // Студопедия. - URL: http://studopedia.net/2_35239_vliyanie-na-cheloveka-otrabotavshihgazov-avtomobiley.html (дата обращения: 17.11.2021).

2. Влияние сажи на здоровье человека. - Текст: электронный // Всемирная организация здравоохранения. Европейское региональное бюро. - URL: https://www.euro.who.int/ru/publications/abstracts/health-effects-of-black-carbon-2012 (дата обращения: 17.11.2021).

3. Воздействие оксида углерода на организм человека. - Текст: электронный // Евро-лаб. Газоанализаторы и системы контроля воздуха. - URL: http://eurolabgas.ru/vozdeystvie_oksida_ugleroda_na_orga (дата обращения: 17.11.2021).

4. Голдовская Л.Ф. Воздействие оксидов азота на организм человека и растения. - Текст: электронный // Информационно-образовательный портал Veni Vidi Vici. - URL: http://www.vevivi.ru/best/Vozdeistvie-oksidov-azota-na-organizm-cheloveka-i-rasteniyaref82310.html (дата обращения: 17.11.2021).

5. Доклад об экологической ситуации в Приморском крае в 2020 году. - Текст: электронный // Официальный сайт Правительства Приморского края и органов исполнительной власти Приморского края. - URL: https://www.primorsky.ru/ authorities/executive-agencies/departments/environment/protivodeystvie-

korruptsii/ДОКЛАД\%20об\%20экологической\%20ситуации\% 20 в \%20Приморском\%20к рае\%20(2020\%20год).pdf (дата обращения: 17.11.2021).

6. Мешков Н.А., Вальцева Е.А. Особенности эколого-гигиенической ситуации и состояния здоровья населения в крупных промышленных городах // Международный журнал прикладных и фундаментальных исследований. - 2018. - № 9. - С. 50-57.

7. Оценка опасности воздействия химических веществ на здоровье населения крупного промышленного города / Н. А. Мешков, Е. А. Вальцева, И. Б. Андрюшин [и др.] // Международный журнал прикладных и фундаментальных исследований. - 2019. № 4. - C. 121-129. 
8. Постановление Главного государственного санитарного врача РФ от 28 января 2021 г. № 2 «Об утверждении санитарных правил и норм СанПиН 1.2.3685-21 «Гигиенические нормативы и требования к обеспечению безопасности и (или) безвредности для человека факторов среды обитания». - Текст: электронный // ГАРАНТ. Информационно-правовое обеспечение. - URL: https://base.garant.ru/400274954/ (дата обращения: 17.11.2021).

9. Санитарно-эпидемиологические правила и нормативы СанПиН 2.2.1/2.1.1.1200-03 «Санитарно-защитные зоны и санитарная классификация предприятий, сооружений и иных объектов» (новая редакция). - Текст: электронный // ГАРАНТ. Информационноправовое обеспечение. - URL: https://base.garant.ru/12158477/ b89690251be5277812a78962f6302560/ (дата обращения: 17.11.2021).

10. Сорокин Н. Д. Охрана окружающей среды на предприятии. - Санкт-Петербург: Вис, 2016. $-690 \mathrm{c.}$

11. Сорокин Н. Д. Справочник нормативно-правовых актов по вопросам охраны окружающей среды и обеспечению экологической безопасности. - Санкт-Петербург: Интеграл, 2017. - 320 с.

12. Федеральный закон от 10.01.2002 № 7-Ф3 (ред. от 02.07.2021) «Об охране окружающей среды». - Текст: электронный // КонсультантПлюс. - URL: http://www.consultant.ru/document/cons_doc_LAW_34823/a646b4197509ac4f8583b190e3 b018fc27f3ae35/ (дата обращения: 17.11.2021).

\section{Транслитерация}

1. Vliyanie na cheloveka otrabotavshih gazov avtomobilej. - Tekst: elektronnyj // Studopediya. - URL: http://studopedia.net/2_35239_vliyanie-na-cheloveka-otrabotavshihgazov-avtomobiley.html (data obrashcheniya: 17.11.2021).

2. Vliyanie sazhi na zdorov'e cheloveka. - Tekst: elektronnyj // Vsemirnaya organizaciya zdravoohraneniya. Evropejskoe regional'noe byuro. - URL: https://www.euro.who.int/ru/publications/abstracts/health-effects-of-black-carbon-2012 (data obrashcheniya: 17.11.2021).

3. Vozdejstvie oksida ugleroda na organizm cheloveka. - Tekst: elektronnyj // Evro-lab. Gazoanalizatory i sistemy kontrolya vozduha. - URL: http://eurolabgas.ru/ vozdeystvie_oksida_ugleroda_na_orga (data obrashcheniya: 17.11.2021).

4. Goldovskaya L.F. Vozdejstvie oksidov azota na organizm cheloveka i rasteniya. - Tekst: elektronnyj // Informacionno-obrazovatel'nyj portal Veni Vidi Vici. - URL: http://www.vevivi.ru/best/Vozdeistvie-oksidov-azota-na-organizm-cheloveka-i-rasteniyaref82310.html (data obrashcheniya: 17.11.2021).

5. Doklad ob ekologicheskoj situacii v Primorskom krae v 2020 godu. - Tekst: elektronnyj // Oficial'nyj sajt Pravitel'stva Primorskogo kraya i organov ispolnitel'noj vlasti Primorskogo kraya. - URL: https://www.primorsky.ru/ authorities/executiveagencies/departments/environment/protivodeystvie-korruptsii/DOKLAD\% 20ob\%20 ekologicheskoj\%20situacii\%20v\%20Primorskom\%20krae\%20(2020\%20god).pdf (data obrashcheniya: 17.11.2021).

6. Meshkov N. A., Val'ceva E. A. Osobennosti ekologo-gigienicheskoj situacii i sostoyaniya zdorov'ya naseleniya v krupnyh promyshlennyh gorodah // Mezhdunarodnyj zhurnal prikladnyh i fundamental'nyh issledovanij. - 2018. - № 9. - S. 50-57.

7. Ocenka opasnosti vozdejstviya himicheskih veshchestv na zdorov'e naseleniya krupnogo promyshlennogo goroda / N. A. Meshkov, E. A. Val'ceva, I. B. Andryushin [i dr.] // Mezhdunarodnyj zhurnal prikladnyh i fundamental'nyh issledovanij. - 2019. - № 4. S. 121-129. 
8. Postanovlenie Glavnogo gosudarstvennogo sanitarnogo vracha RF ot 28 yanvarya $2021 \mathrm{~g}$. № 2 «Ob utverzhdenii sanitarnyh pravil i norm SanPiN 1.2.3685-21 «Gigienicheskie normativy i trebovaniya $\mathrm{k}$ obespecheniyu bezopasnosti i (ili) bezvrednosti dlya cheloveka faktorov sredy obitaniya». - Tekst: elektronnyj // GARANT. Informacionno-pravovoe obespechenie. - URL: https://base.garant.ru/400274954/ (data obrashcheniya: 17.11.2021).

9. Sanitarno-epidemiologicheskie pravila i normativy SanPiN 2.2.1/2.1.1.1200-03 «Sanitarnozashchitnye zony i sanitarnaya klassifikaciya predpriyatij, sooruzhenij i inyh ob"ektov» (novaya redakciya). - Tekst: elektronnyj // GARANT. Informacionno-pravovoe obespechenie. - $\quad$ URL: https://base.garant.ru/12158477/ b89690251be5277812a78962f6302560/ (data obrashcheniya: 17.11.2021).

10. Sorokin N. D. Ohrana okruzhayushchej sredy na predpriyatii. - Sankt-Peterburg: Vis, 2016. $-690 \mathrm{~s}$.

11. Sorokin N. D. Spravochnik normativno-pravovyh aktov po voprosam ohrany okruzhayushchej sredy i obespecheniyu ekologicheskoj bezopasnosti. - Sankt-Peterburg: Integral, 2017. $-320 \mathrm{~s}$.

12. Federal'nyj zakon ot 10.01.2002 № 7-FZ (red. ot 02.07.2021) «Ob ohrane okruzhayushchej sredy». - Tekst: elektronnyj // Konsul'tantPlyus. - URL: http://www.consultant.ru/document/cons_doc_LAW_34823/a646b4197509ac4f8583b190e 3b018fc27f3ae35/ (data obrashcheniya: 17.11.2021).

() И.Ю. Гриванов, 2021

(C) Е.В. Тарасова, 2021

(с) И.В. Кучма, 2021

Для цитирования: Гриванов М. Ю., Тарасова Е. В., Кучма И. В. Прогнозирование состояния атмосферного воздуха в результате деятельности Новоспасского цементного завода АО «Спасскцемент» // Территория новых возможностей. Вестник Владивостокского государственного университета экономики и сервиса. - 2021. - Т. 13, № 4. C. 199-213.

For citation: Grivanov I. Yu., Tarasova E. V., Kuchma I. V. Forecasting the state of atmospheric air as a result of the activities of the No-vostassky cement plant JSC "Spasskcement", The Territory of New Opportunities. The Herald of Vladivostok State University of Economics and Service, 2021, Vol. 13, № 4, pp. 199-213.

DOI https://doi.org/10.24866/VVSU/2073-3984/2021-4/199-213

Дата поступления: $\quad$ Одобрена после рецензирования: $\quad$ Принята к публикации:

